\title{
Militarización e identidades políticas en la revolución rioplatense*
}

\author{
Beatriz Bragoni y Sara Mata de López \\ CONICET-CRICYT/CONICET-UNSa
}

Las revoluciones de independencia hispanoamericanas han ocupado un lugar destacable en la nueva agenda de la historia política. Este trabajo se propone explorar los procesos de construcción de identidades políticas a partir de la militarización y la guerra experimentadas en las jurisdicciones de las provincias de Salta y Cuyo integradas en el Virreinato rioplatense en 1776. Además, se pretende dar cuenta de los beneficios de ejercicios comparativos que ayudan a despejar las especificidades regionales en relación a la marea revolucionaria desencadenada en los dominios españoles americanos desde 1808.

PALABRAS CLAVE: revolución rioplatense, militarización, identidades políticas, espacios locales.

The revolutions of the Hispanic American independence have occupied an outstanding place in the new agenda of the political history. This paper proposes to explore the processes for constructing the political identities starting from the militarization and war experimented in the jurisdictions of the Salta and Cuyo provinces, integrated to the Rio de la Plata Viceroyship as from 1776. The work takes into account the benefit of comparative exercises that aid in the enlightenment of regional specificities assumed when dealing with the revolutionary wave unleashed in the Spanish American domains since 1808.

KEYWORDS: "rioplatense" revolution, militarization, political identities, local spaces.

Las revoluciones de independencia hispanoamericanas han ocupado un lugar destacable en la nueva agenda de la historia política al presentar innumerables problemas de la más variada índole, además todas estas revoluciones se han visto atravesadas por la experiencia de una situación inédita: la guerra civil y social que sacudió a las colonias españolas en América. En ese contexto las jurisdicciones del antiguo Virreinato del Río de la Plata sufrieron procesos de identidad política y social que se expresaron posteriormente en la dimensión territorial. Atentas a los beneficios de ejercicios comparativos que ayudan a despejar las especificidades regionales asumidas frente a la marea revolucionaria desencadenada en los dominios espa-

* Este artículo forma parte del Proyecto PIP 6073 del CONICET. La documentación citada correspondiente al Archivo General de Indias se consultó gracias a una Beca de la Residencia de la Escuela de Estudios Hispanoamericanos de Sevilla en abril de 2006. 
ñoles americanos a partir de $1808,{ }^{1}$ este trabajo propone explorar estos procesos de construcción de identidades políticas a partir de la militarización y la guerra experimentadas en las jurisdicciones de las provincias de Salta y Cuyo integradas en el Virreinato rioplatense a partir de 1776.

En los últimos treinta años la historiografía argentina ha mejorado la comprensión del fenómeno revolucionario, enfatizando particularmente el análisis de los lenguajes e ideas políticas, la emergencia de la opinión pública, los dilemas referidos a soberanía y representación, y los fenómenos sociales afincados en la sociabilidad de las elites así como de otros grupos sociales, acerca de los cuales se han obtenido avances significativos. ${ }^{2}$ Sin embargo, los problemas vinculados a la guerra que se desencadena como consecuencia del movimiento revolucionario en Buenos Aires - y posteriormente expandido a toda la jurisdicción rioplatense - no han merecido aún abordajes sistemáticos capaces de problematizar el peso de la militarización y de la experiencia guerrera en la formación de identidades políticas colectivas que no necesariamente están vinculadas con las nacionalidades "imaginadas" después de $1830 .^{3}$ Más exactamente, el estudio de

1 Uribe Urán, Víctor Manuel, y Ortiz Mesa, Luis Javier: Naciones gentes y territorios. Ensayos de historia e historiografía comparada de América Latina y el Caribe, Editorial Universitaria de Antioquía, Colombia, 2000.

2 La literatura es abundante. Citamos aquí los trabajos más representativos: Halperin Donghi, Tulio: Tradición española e ideología de mayo, CEAL, Buenos Aires, 1988 (1ª edición, 1963); Chiaramonte, José C.: "Formas de identidad política en el Río de la Plata después de la independencia", Boletín Ravignani, n. ${ }^{\circ}$ 1, 1989; "El federalismo argentino en la primera mitad del siglo XIX" en Carmagnani, M.: Los federalismos latinoamericanos. México, Brasil, Argentina, Fondo de Cultura Económica, México, 1994; "Acerca del origen del estado en el Río de la Plata", Anuario-IEHS, Tandil, n. ${ }^{\circ} 10,1995$ y Ciudades, provincias, Estados: Orígenes de la Nación Argentina, 1800-1846, Ariel, Buenos Aires, 1997. Myers, Jorge: Orden y virtud. El discurso republicano durante el rosismo, UNQu, 1995; González Bernaldo de Quirós, Pilar: Civilité et politique aux origines de la nation argentine. Les sociabilités à Buenos Aires, 1829-1862, Publicacions de la Sorbonne, 1999; Cansanello, O.: "De súbditos a ciudadanos. Los pobladores rurales bonaerenses entre el Antiguo Régimen y la Modernidad", en Boletín Ravignani, 11,1995; Ternavasio, Marcela: La revolución del voto. Política y elecciones en Buenos Aires, 1810-1852, Buenos Aires, Siglo XXI, 2001.

3 Para el caso argentino el pionero estudio de Pilar González Bernardo de Quirós y de Jorge Myers se convierte en una excepción de una saga de estudios que optan por acentuar las nociones antigeneologistas de las naciones y los nacionalismos. Véase González Bernaldo, Pilar: "La 'identidad nacional' en el Río de la Plata post-colonial. Continuidades y rupturas con el Antiguo Régimen", Anuario IEHS, n. ${ }^{\circ}$ 12, 1997. Además, Myers, Jorge: "Identidades porteñas. El discurso ilustrado en torno la nación y el rol de la prensa: El Argos de Buenos Aires, 1821-1825", en Alonso, Paula (comp.): Construcciones impresas. Panfletos, diarios y revistas en la formación de los estados nacionales en América Latina, 1820-1920, Fondo de Cultura Económica, Buenos Aires 2003, págs. 39-63. Para un balance de la producción historiográfica reciente sobre la revolución rioplatense y el problema de los orígenes, véase Halperin Donghi, Tulio: "Los orígenes de la nación argentina, un tema que retorna”, Entrepasados. Revista de Historia, Año X, 20/21, 2001 y "Del virreinato del Río de la Plata a la nación argentina” en Mínguez, Víctor, y Chust, Manuel (eds.): El imperio sublevado, CSIC, Madrid, 2004, págs. 277-288. 
la conformación de identidades políticas durante las guerras de independencia tiene ya antecedentes en la literatura hispanoamericana más reciente. No pocos historiadores han comenzado a reparar sobre la importancia de la dinámica de la guerra de independencia en cuanto forjadora de identidades políticas. Como ha señalado en una reciente publicación Clément Thibaud "si las naciones no preexistían a la independencia eran entonces su consecuencia". ${ }^{4}$ En este sentido, y así como la mutación política producida a partir de la revolución precipita una nueva legitimidad, aquélla eleva a la guerra como ámbito de resolución política. Es por esto que nos proponemos ensayar a partir del estudio de la dinámica de la guerra en la jurisdicción rioplatense una interpretación plausible de las diferentes identificaciones generadas a partir de la condición de "americanos" a la cual apelaron tanto los insurgentes como los fidelistas en los territorios ultramarinos de la "Nación Española".5

Tulio Halperin Donghi hace ya varias décadas ofreció un inmejorable cuadro de las especificidades de la revolución rioplatense, atendiendo a los diferentes escenarios de la revolución en el interior. ${ }^{6}$ Desde entonces han sido muy escasos los trabajos que han indagado las inflexiones territoriales y políticas producidas por los ritmos ambivalentes del proceso revolucionario y de la guerra que se disparó de inmediato en toda la jurisdicción hasta entonces virreinal. El historiador argentino al restituir el proceso de formación de las elites revolucionarias tuvo en cuenta la importancia de la guerra aunque centrándola en las dinámicas dirigidas desde el centro revolucionario. De este modo, los poderes locales terminan convirtiéndose en cajas de resonancia de la política dirigida desde la capital cuando en realidad experimentan sus propias dinámicas revolucionarias.

Analizar la revolución y la guerra en el interior del Virreinato del Río de la Plata supone a nuestro juicio reparar en algunas especificidades. Aunque ambas ciudades - provincias manifestaron adhesión primero a la Junta de gobierno porteña creada en 1810, y más tarde al poder central instalado en la antigua capital del Virreinato, Salta lo hacía en carácter de capital de la Intendencia de Salta del Tucumán, mientras que Cuyo la utili-

4 Thibaud, Clément: "Formas de guerra y mutación del ejército durante la guerra de independencia en Colombia y Venezuela" en Rodríguez, Jaime (coord.): Revolución, independencia y las nuevas naciones de América, MAFRE/Tavera, Madrid, 2005, pág. 233.

5 Elliott, J. H.: "Rey y patria en el mundo hispánico" en Mínguez, Víctor, y Chust, Manuel (eds.): El imperio sublevado, CSIC, Madrid, 2004.

6 Halperin Donghi, Tulio: Revolución y Guerra. La formación de una elite dirigente en la Argentina criolla, Siglo XXI, Buenos Aires, 1979. 
zaba como estrategia diferenciada de Córdoba, ciudad capital de intendencia, con quien mantenía antiguas controversias, con el fin de recuperar la autonomía perdida desde $1782 .{ }^{7}$

A pesar de estas marcadas diferencias sociales y políticas, la crítica coyuntura de 1814 condicionó el desarrollo político de ambos espacios. Aunque sería sobre todo a partir de 1815 cuando las dos gobernaciones exhibieron una notable articulación de acciones orientadas a sostener el gobierno de las Provincias Unidas centradas en la antigua capital del Virreinato. ¿Qué razones explican esa solidaridad política? ¿En qué medida esa solidaridad representa o favorece la conformación de una identidad política que se reconoce en una comunidad que supera la local? Sin ánimo de retomar visiones genealogistas sobre los orígenes de las nacionalidades, ${ }^{8}$ este trabajo se propone reflexionar acerca del papel que desempeñaron los poderes locales en el proceso revolucionario y de qué manera la militarización experimentada tanto en Salta como en Cuyo se tradujo en identidad política de contornos más complejos que la estricta dimensión local. Para ello consideramos necesario prestar atención a los conflictos locales y a la presencia de los ejércitos en el contexto de la guerra de la independencia.

Para responder a estos interrogantes consideramos importante en primer lugar atender a los diferentes procesos de militarización que operan en ambas jurisdicciones para luego avanzar en la caracterización de la solidaridad política manifestada hacia 1815 entre estos poderes locales y el poder central; finalmente, proponemos aproximarnos al fenómeno de las identidades políticas colectivas en relación con la guerra, tratando de mejorar la compresión de las inflexiones de la cultura política.

\section{Guerras, ejércitos y milicias}

La revolución en Buenos Aires y la adhesión de las ciudades del interior del Virreinato del Río de la Plata a la Junta instalada en Buenos Aires se sostuvo gracias al uso de la fuerza militar. Para sofocar los primeros

7 Hasta 1776 la región de Cuyo había integrado la antigua Capitanía de Chile; el giro de autoridad dado por la administración borbónica generó no pocas controversias entre las ciudades cuyanas (Mendoza, San Juan y San Luis) frente a la capital cordobesa. Comadrán Ruiz, Jorge: "Mendoza en 1810" Actas del III Congreso Internacional de Historia de América, tomo IV, Academia Nacional de la Historia, Buenos Aires, 1961.

8 Una problematización del concepto genealógico y algunos reparos puestos a las perspectivas antigenealógicas, véase Palti, Elías: La nación como problema. Los historiadores y la "cuestión nacional", Fondo de Cultura Económica, Buenos Aires, 2003. 
focos contrarevolucionarios fue preciso organizar una fuerza militar, movilizando las milicias veteranas de Buenos Aires y procediendo a reclutar hombres que integrarían el denominado Ejército Auxiliar de Perú destinado a recuperar las principales ciudades altoperuanas que, ante los acontecimientos que tuvieron lugar en la capital virreinal, solicitaron retornar a la jurisdicción del Virreinato de Perú, desconociendo así la autoridad de la Junta de Buenos Aires.

El escenario de la guerra se instaló primordialmente en el Alto Perú y fue protagonizada tanto por los ejércitos realista y porteño como por las guerrillas movilizadas en el ámbito rural altoperuano. Los vaivenes de la guerra involucraron hasta 1821 a la Intendencia de Salta del Tucumán, particularmente a Salta, ciudad capital, y a Jujuy por la vinculación de ambas a los andes meridionales.

Tras unos primeros años caracterizados por triunfos militares y derrotas, en 1814 la revolución rioplatense atravesaba serios obstáculos como consecuencia de la restitución de Fernando VII al trono de España que radicalizó el conflicto. De mayor gravedad para la estabilidad del Gobierno de Buenos Aires fue el triunfo realista en Rancagua, en octubre de 1814, que les permitió recuperar Santiago y el antiguo reino de Chile, constituyéndose en una amenaza para los "insurgentes porteños", al favorecer la posibilidad de avanzar sobre Cuyo y pasar desde allí a Córdoba y a Buenos Aires. En el contexto de esa estrategia militar incursionaron en 1814 con éxito en Salta y Jujuy, ciudades que ocuparon sin grandes dificultades a principios de ese año, como consecuencia de las derrotas sufridas en el Alto Perú por el ejército de Manuel Belgrano el año anterior. Los caudillos altoperuanos libraron una guerra de guerrillas que jaquearon al Ejército realista, contribuyendo a descomprimir la situación militar en las jurisdicciones de Salta y Jujuy, ya que se vieron obligados a abandonarlas, tanto por el hostigamiento al cual eran sometidos por las milicias locales lideradas por Martín Miguel de Güemes, como por la necesidad de desbaratar las fuerzas irregulares que combatían en el Alto Perú. Influyeron también en esta decisión las noticias acerca de la caída de Montevideo, que les restaba una base de apoyo importante para avanzar hacia Buenos Aires.

En efecto, significó un fuerte revés para la estrategia del ejército realista el retiro, para ellos inexplicable, de la colaboración portuguesa, que abandonó a su suerte a la plaza de Montevideo y permitió a Buenos Aires concluir con ese reducto fidelista. La recuperación de Montevideo radicalizó el enfrentamiento de José de Artigas, quien hasta entonces había lide- 
rado la revolución en la Banda Oriental, ${ }^{9}$ con las autoridades de Buenos Aires, quienes veían en su liderazgo una firme oposición a sus intereses hegemónicos plasmados en un proyecto político centralizador. ${ }^{10}$

En este escenario el régimen revolucionario sufrió cambios significativos. El poder ejecutivo en Buenos Aires se transformó en unipersonal con la designación de Gervasio Posadas como Director Supremo de las Provincias Unidas del Río de la Plata, quien de inmediato dispuso la división de la Intendencia de Salta y la creación, a partir de su jurisdicción, de las provincias de Salta y de Tucumán. Esta medida de gobierno fue interpretada como una disposición tendente a generar mayores apoyos políticos en el interior, ${ }^{11}$ pero también puede entenderse como una medida adoptada con la finalidad de debilitar el creciente poder en Salta de Martín Miguel de Güemes, al restarle los recursos fiscales procedentes de Tucumán. ${ }^{12} \mathrm{La}$ especificidad de la experiencia salteña en la guerra de independencia deriva precisamente del liderazgo político y militar de Güemes quien entre los años 1814 y 1821 condujo con habilidad la resistencia a las tropas realistas. Este liderazgo ascendente de Güemes incomodará a las autoridades de Buenos Aires, que observaban con recelo su creciente poder. ${ }^{13}$

El año 1814 marca un punto de inflexión en Salta. En primer lugar, se produjo una movilización rural hasta ese momento desconocida, ya que si bien existían milicias locales, que apoyaban al ejército de Buenos Aires, hasta ese año la revolución no entusiasmaba demasiado a la población

9 La ciudad de Montevideo fue el bastión realista en el Río de la Plata hasta 1814. Se encontraba allí la Marina Real y la secular rivalidad de los comerciantes de ese puerto con los de Buenos Aires favoreció su fidelismo. El hinterland de la ciudad, conocido como Banda Oriental, se insurreccionó con el liderazgo de José de Artigas quien con ocasión de la realización de la Asamblea Constituyente de 1813 presentó propuestas fuertemente diferenciadas de las preconizadas por Buenos Aires.

10 París de Oddone, Blanca: "Presencia de Artigas en la revolución del Río de la Plata (18101820)", en Frega, Ana, e Islas, Ariadna (coord.): Nuevas miradas en torno al artiguismo, Departamento de Publicaciones de la Facultad de Humanidades y Ciencias de la Educación, Montevideo, 2001; Frega, Ana: "Caudillos y montoneras en la revolución radical artiguista", Andes 13, Cepiha-Salta, 2002, págs. $75-110$.

11 Halperin Donghi, Tulio: Revolución y Guerra. La formación de una elite dirigente en la Argentina criolla, Siglo XXI, Buenos Aires, 1979.

12 El primer historiador que rescata la controvertida figura de Güemes fue Frías, Bernardo: Historia del General Martín Miguel de Güemes y de la Provincia de Salta [1909], Editorial De Palma, Buenos Aires, 1970, 7 tomos. De la bibliografía referida a la figura de Martín Miguel de Güemes merece mencionarse el libro de Cornejo, Atilio: Martín Miguel de Güemes, Fondo Editorial, Buenos Aires, 1947, que brinda abundante información sobre el accionar guerrero y los antecedentes familiares de Güemes.

13 Mata de López, Sara: "La guerra de independencia en Salta y la emergencia de nuevas relaciones de poder" en Andes, n. ${ }^{\circ}$ 13, CEPIHA, Facultad de Humanidades, UNSa, 2003, págs. 113-143. 
rural, con excepción de las milicias movilizadas de la frontera, más militarizada y experimentada por su conflictiva relación con los pueblos chaqueños. La población de los valles, en cambio, respondía con reticencias a la recluta y se incorporó en escasa medida al ejército Auxiliar de Perú. A diferencia de lo acontecido en 1813, cuando el ejército porteño logró derrotar a las huestes realistas, con la colaboración de las milicias regladas pero sin una movilización generalizada de la población, en 1814 se produjo un levantamiento campesino en el valle de Lerma, a pocas leguas de la ciudad de Salta, que acosó a las partidas del general Joaquín de la Pezuela cuando éste dispuso la confiscación de ganado vacuno y mular para abastecer a sus tropas. Pequeños propietarios, arrenderos y agregados de las estancias del valle resistieron al saqueo, liderados por jefes de las milicias rurales e incluso por medianos propietarios ${ }^{14}$ Esta movilización, en cierta medida espontánea, significará el inicio de un movimiento social que, a lo largo de la guerra en los andes del Sur, resultará de fundamental importancia tanto para comprender las luchas facciosas a nivel local, como para establecer las bases de un proceso de identidad política en la cual estará presente el reconocimiento a la autoridad de Buenos Aires y la estrecha vinculación económica y política con el Alto Perú. ${ }^{15}$

En este contexto de crisis y violencia se manifestarán con claridad las diferentes facciones políticas de la elite dirigente embarcada en la revolución. Si desde Buenos Aires se observaba con temor la acción de Güemes, los vecinos de las ciudades de Salta, de Tucumán y de Jujuy veían menguar sus posibilidades de ascenso político ante su arrollador liderazgo basado

14 Los movimientos insurgentes en el contexto de la guerra de independencia, así como los motines y rebeliones que tuvieron lugar tanto en el espacio andino como en la América española a finales de la colonia, han dado lugar a un interesante desarrollo historiográfico, si bien resta aun mucho por investigar. Señalaremos tan solo algunos de trabajos más relevantes y de obligada referencia, entre ellos Van Young, Eric: La crisis del orden colonial: estructura agraria y rebeliones populares en la Nueva España, 1750-1821, FCE, México, 1992; Walter, Charles (comp.): Bandoleros, abigeos y montoneros. Criminalidad y violencia en el Perú. Siglos XVIII-XX, Instituto de Apoyo Agrario, Lima, Perú, 1990; Walter, Charles: De Túpac Amaru a Gamarra. Cusco y la formación del Perú republicano 17801840, Centro de Estudios Regionales Andinos "Bartolomé de las Casas", Cuzco, Perú, 1999; Flores Galindo, Alberto (comp.): Independencia y revolución. 1780-1840, Instituto Nacional de Cultura, Lima, Perú, 1987.

15 En 1812 cuando el General realista Pío Tristán recuperó la ciudad de Salta recibió apoyo local para sustentar a su ejército. Su derrota significó la migración de las familias más comprometidas en ese apoyo, restando así posibilidades de aprovisionamiento a las siguientes ocupaciones realistas. Por esta razón, Joaquín de la Pezuela — carente de alimentos, ganado vacuno y mulas — se vio precisado de recurrir a las confiscaciones. Véase Mata de López, Sara: "Tierra en Armas. Salta en la revolución” en Mata de López, S. (comp.): Persistencias y Cambios. El noroeste argentino 1770-1840, Prohistoria, Rosario, págs. 149-175. 
fundamentalmente en el apoyo de las milicias de Salta, Jujuy y Tarija, a la cual se sumaban voluntarios para hacer frente a la presencia realista. La rivalidad política y militar se explicitó en torno a la capacidad de movilización militar, a la construcción de poder político y a la relación con las autoridades porteñas. ${ }^{16}$ En el plano local la adhesión a Buenos Aires realineó a los sectores de la elite y entre quienes apoyaron a la Junta de Buenos Aires se encontraron diferentes facciones de la misma, que si bien coincidieron en el reconocimiento a la Junta, no por ello menguaron en sus enfrentamientos para monopolizar el poder. Miembro de una familia que carecía de relevancia en la elite de Salta, aunque estrechamente vinculada a ella, Güemes en su condición de militar debió enfrentar en Salta la rivalidad del poderoso hacendado José Antonino Fernández Cornejo, Comandante de la Frontera, quien intentó con el apoyo del Director Supremo, Álvarez Thomas, y del Jefe del Ejército del Norte, José de Rondeau, organizar las milicias de Salta y Jujuy tras el retiro de las tropas del General Realista, Joaquín de la Pezuela, en julio de 1814. ${ }^{17}$

La militarización cuyana exhibió un ritmo diferente al salteño en la medida en que el éxito de la revolución chilena no exigió la presencia de un ejército en su jurisdicción hasta 1813; hasta ese momento la movilización se limitó al reclutamiento de hombres de acuerdo a la normativa de 1801, y a la provisión de recursos con destino al Ejército Auxiliar de Perú. Sin embargo, el avance realista sobre el bastión patriota chileno condujo al

16 Martín Güemes integró indudablemente redes políticas y militares que deben aún profundizarse mejor. Desde muy joven tuvo oportunidad de establecer vinculaciones en la Capital del Virreinato al incorporarse, en calidad de cadete, al Regimiento Fijo de Buenos Aires. Participó en la defensa de Buenos Aires con ocasión de las invasiones inglesas y en 1810 ingresó en el Ejército Auxiliar del Norte participando de la primera expedición al Alto Perú. Por diferencias con sus superiores fue separado del mismo y enviado a Buenos Aires en 1812. Allí fue asignado al asedio de Montevideo. Véase Cornejo, Atilio: Historia de Güemes... Es indudable que esta trayectoria militar le granjearía amistades y enemigos en Buenos Aires. Su excelente relación con Juan Martín de Pueyrredón contrasta notablemente con la aversión que siente por José María de Alvear, Álvarez Thomas y Posadas. La amistad con Pueyrredón remite también a relaciones establecidas por su padre, Tesorero de la Real Hacienda de la Intendencia de Salta, con Diego de Pueyrredón, tío de Juan Martín, cuando éste fuera Comandante de Frontera de Jujuy. Ahora bien, la pregunta que se impone es si esas adversiones y simpatías remiten sólo a relaciones personales o incluyen también proyectos políticos diferentes. Sobre esto último no tenemos aún suficiente evidencia.

17 Da prueba de la dureza del enfrentamiento de Güemes con Cornejo abundante documentación. En un oficio enviado al Director Supremo en agosto de 1815, Mariano Gordaliza, Teniente de Gobernador de Jujuy, informaba acerca de la imposibilidad de organizar las milicias de Jujuy por el hostigamiento de Güemes y agregaba que tampoco podía organizarse "...el de Partidarios del Sr. D. Antonino Fernández Cornejo porque éste se halla como desterrado en Salta...” Oficio del Teniente de Gobernador de Jujuy al Exmo. Sr. Director Supremo del Estado. AGN. Sala 10. 4.1.2. 
gobierno central a introducir cambios significativos en Cuyo para sostener la frontera revolucionaria. Esa nueva coyuntura no sólo elevó el status de las ciudades cuyanas al integrar una nueva gobernación con capital en Mendoza, sino que fortaleció los lazos con el centro político a través del nombramiento y envío de gobernadores intendentes de confianza con el fin de sostener el curso revolucionario: Juan Florencio Terrada y Marcos González Balcarce reunían trayectorias favorables a la independencia americana, moldeadas a través de experiencias asociativas iniciadas en Cádiz o en el Río de la Plata. ${ }^{18}$ Aunque los nuevos funcionarios implementaron acciones para acelerar la militarización, la escasez de recursos limitó su alcance: la imposición de contribuciones forzosas dio origen a conflictos en los Cabildos de Mendoza y San Juan, y la exiguas cuotas obtenidas en el primer trimestre de 1814 fueron destinadas al ejército de Perú por orden del gobierno central. Por otra parte, la formación de cuerpos de infantería y caballería (pardos y blancos) se había visto afectada ante los sucesivos requerimientos del gobierno de Buenos Aires para surtir batallones en la campaña sobre Montevideo, y en el auxiliar del "Estado de Chile". Por consiguiente, las condiciones de defensa en Cuyo estaban limitadas a cuerpos milicianos organizados por los Cabildos, en ciudad y campaña, y a la raquítica tropa regular representada por el cuerpo de blandengues acantonado en el valle de Uco. ${ }^{19}$

18 Juan Florencio Terrada (1782-1824) era oficial de milicias en Buenos Aires destacándose en las invasiones inglesas: en 1807 fue ascendido a teniente coronel del batallón Granaderos de Fernando VII; asistió al cabildo abierto del 22 de mayo y firmó el acta que exigía la renuncia de Cisneros. Después de participar en las negociaciones que provocaron el cese del bloqueo de Buenos Aires, en 1811 como coronel del ejército porteño, se incorporó al ejército sitiador de Montevideo. Entre diciembre de 1813 y agosto de 1814, se desempeñó como gobernador intendente de Cuyo. Según sus biógrafos, participó de la Sociedad de Caballeros Racionales en Cádiz integrándose más tarde en la "Gran Logia de Buenos Aires"; esas relaciones explican su posterior desempeño como Ministro de Guerra bajo la administración de Pueyrredón. A partir de los vínculos de su tío el canónigo Juan Pablo Fretes, forjó una sólida amistad con el chileno Bernardo de O'Higgins. El desempeño de Marcos Balcarce fue muy breve y partió al mando del Cuerpo Expedicionario a Chile en apoyo de la revolución chilena.

19 Aunque la profusa literatura sanmartiniana alude al giro dado por San Martín a la militarización en Cuyo, existen diferencias a la hora de evaluar el peso de las milicias regladas en su organización. En tal sentido Comadrán Ruiz atribuye al período borbónico y a la gestión de Sobremonte, como comandante general de armas, un lugar privilegiado que prepara a los cuyanos en aspectos ligados al entrenamiento y a la obediencia militar. Comadrán Ruiz, Jorge: "Cuyo y la formación del ejército de los Andes. Consecuencias socio-económicas", Congreso Internacional Sanmartiniano, Buenos Aires, 1978 y "Las milicias regladas de Mendoza y su papel en el Ejército de los Andes", Diario Mendoza, julio 1979. Además, Pelagatti, Oriana: "Conflictos y autoridad en la frontera sur durante la Revolución, Mendoza 1810-1816”, VII Seminario argentino chileno y I Seminario Cono Sur de Ciencias Sociales, Humanas y Relaciones Internacionales. El Cono Sur frente al Bicentenario, Universidad de Congreso, Mendoza, 2004. 
Esa situación se modificó sustancialmente ante la llegada del nuevo gobernador intendente, el coronel José de San Martín, otro de los oficiales del ejército real salidos de la península que desembarcaron en Buenos Aires en 1812, integrándose a las jerarquías militares de los insurgentes porteños a través del vector patriótico lautarino, y que, después de haber conocido el malogrado ejército del Norte, habría de encabezar un giro significativo en la conducción de la guerra dirigida desde Buenos Aires. La construcción de un consenso local afín a su liderazgo y de la concepción centralizada del poder que representaba, se robusteció ante la derrota de los patriotas chilenos en Rancagua en octubre de 1814. Ante la amenaza inminente del avance realista a Cuyo, los grupos mercantiles cuyanos, que mantenían estrechos vínculos con las plazas chilenas y de Buenos Aires, no tardaron en manifestar su solidaridad a la empresa militar, depositando en ella expectativas favorables con el fin de restablecer su intermediación entre los mercados del Pacífico y el puerto de Buenos Aires. ${ }^{20}$

San Martín dirigió un proceso de militarización inédito destinado a emprender una estrategia ofensiva para lo cual resultaba indispensable formar soldados entrenados y apertrechados para hacer la guerra. Dirigida "desde arriba", y sostenida por una tupida red de aliados locales, integrada por funcionarios menores y líderes territoriales, la formación de soldados profesionales - "haremos soldados de cualquier bicho", escribió Tomás Guido a San Martín - exigió la obtención de una renta fija (derivados del gobierno de Buenos Aires y de la extracción de recursos locales) que permitiera asegurar salarios y equipos para garantizar obediencia y eludir la "peste" de la deserción. ${ }^{21}$ El éxito de esa empresa dependió de un esquema de poder local que aparecía articulado por un elenco estable de personajes fieles a la revolución desde sus comienzos. El "gobierno de amigos sólidos" reunía perfiles de trayectorias no siempre bien conocidas, aunque en su mayoría habían ejercido funciones administrativas y/o militares de mayor o menor o jerarquía antes y durante el ciclo revolucionario:22 si los tenientes

20 Acevedo, Edberto: Investigaciones del comercio cuyano 1800-1830, Buenos Aires, Academia Nacional de la Historia, 1981; O'Phelan Godoy, Scarlett, y Guerrero, Cristian: "De las reformas borbónicas a la formación del Estado en Perú y Chile" en Caviares, Eduardo, y Aljovin de Losada, Cristóbal (comp.): Chile-Perú; Perú-Chile en el siglo XIX. La formación del estado, la economía y la sociedad, Ediciones universitarias, Valparaíso, 2005, págs. 25-58.

21 Bragoni, Beatriz: "Guerreros virtuosos, soldados a sueldo. Móviles de reclutamiento militar durante el desarrollo de la guerra de Independencia” en Dimensión Antropológica, Instituto Nacional de Antropología e Historia, México, 2005.

22 El "gobierno de amigos sólidos" aparecía representado por una red de funcionarios que incluía al Cabildo de la capital, los comandantes de frontera y de las milicias también estaba integrado por los decuriones de ciudad y celadores de la campaña. 
gobernadores de San Juan, Ignacio De la Rosa, y de San Luis, capitán Vicente Dupuy, se convirtieron en aliados estables, no fueron menos decisivas las inclusiones del comandante de frontera José Susso y del teniente Manuel Corvalán, quienes sintetizaban carreras profesionales iniciadas en el período virreinal, sea como integrantes de las milicias regladas afincadas en la jurisdicción, o bien como partícipes activos de los contingentes milicianos enviados a Buenos Aires con ocasión de las invasiones inglesas de 1806 y 1807 como integrantes de los batallones de "arribeños". Esos liderazgos intermedios se completaban con una pléyade de magistrados con funciones de policía y justicia, estratégicamente designados para ejercer el control sobre los cuarteles urbanos y rurales. El cabildo de la capital también se convirtió en baluarte del poder sanmartiniano. No obstante, el entendimiento del gobernador con los capitulares estuvo lejos de limar asperezas, ya que si buena parte del poder local se dirimía en torno al Cabildo, el proceso político disparado con la revolución y la militarización que le siguió obligaron a negociaciones e intervenciones que superaban la vigorosa, aunque no excluyente, institución capitular. Es preciso traer a colación al menos tres situaciones convergentes: a) la modificación operada en torno a milicias regladas que introdujo diferencias entre antiguos y nuevos liderazgos: $:^{23}$ allí San Martín, así como sus oficiales leales, fueron custodios fieles de la jerarquía militar a través de la instrumentación de la ecuación prest-obediencia; ${ }^{24}$ b) la necesidad de pactar con las parcialidades indígenas de la frontera sur con el fin de evitar que reprodujeran situaciones semejantes a las exhibidas en la restauración del poder realista en el sur chileno, objetivo que vino de la mano de las relaciones mantenidas con la "nación" pehuenche por el fraile araucano Francisco Inalicán y el comandante de frontera Pedro Susso $;{ }^{25}$ c) las tensiones originadas con motivo de las rivalidades entre la ciudad cabecera y las subalternas que se manifestaron en torno al rechazo de funcionarios nombrados por la autoridad central, y mantenidos por el gobierno de la

23 El conflicto suscitado con motivo de la protesta que el teniente coronel Miguel Villanueva dirigió al Director Supremo por ser enviado a San Luis por el Sargento Mayor Marcos Balcarce, el flamante comandante General de Armas. Documentos para la Historia del Libertador General San Martín, Ministerio de Educación de la Nación, Buenos Aires, 1954, tomo II, págs. 407-410.

24 Halperin Donghi, Tulio: Guerra y finanzas en los orígenes del Estado argentino (17911850), Editorial Belgrano, Buenos Aires, 1982; un trabajo reciente sobre la militarización porteña puede verse en Di Meglio, Gabriel: "Soldados de la Revolución. Las tropas porteñas en la guerra de independencia, 1819-1820”, Anuario IEHS, Tandil, n. ${ }^{\circ} 18,2004$, págs. 39-65.

25 Pelagatti, Oriana: "Religión y política en la frontera sur del antiguo imperio español. Fr. Francisco Inalicán, 1805-1824" en Ayrolo, Valentina (comp.): Estudios sobre clero iberoamericano entre la independencia y el Estado nación, Salta Centro Promocional de las Investigaciones en Historia y Antropología (CEPIHA), Universidad Nacional de Salta. 
capital, que condujo al gobernador intendente a aceptar las nominaciones surgidas de los cabildos abiertos constituidos para tal fin.

La relativa coherencia de esa pirámide de poder dio lugar a una rápida concentración de poder e influencias que se tradujo en una intensa movilización de hombres que recayó especialmente en los sectores subalternos de toda la jurisdicción. Según las fuentes, en el lapso de cien días la leva alcanzó la cifra de 1.200 hombres en ciudad y campaña. Como en Buenos Aires, la reglamentación sobre vagos y mal entretenidos se convirtió en torniquete del reclutamiento militar sobre la población masculina sin trabajo estable, aunque también penetró entre quienes lo tenían: mientras "mestizos y criollos pobres" engrosaron las filas de la caballería, la oficialidad fue integrada por vástagos de familias "aristocráticas". Algunos han calculado que de los 5.187 hombres que integraron el ejército en el momento del cruce de los Andes, 3.610 eran originarios de la jurisdicción cuyana ${ }^{26} \mathrm{El} \mathrm{reclu-}$ tamiento de los esclavos se implementó a través de la compra, confiscación o en reemplazo de hijos de familia exentos del servicio militar: una primera disposición reclutó esclavos de entre 16 y 30 años pertenecientes a europeos peninsulares sin carta de ciudadanía; ${ }^{27}$ después la leva avanzó sobre toda la jurisdicción cuyana a través de la formación de una comisión ad hoc encargada de reclutar a las dos terceras partes de esclavos útiles en el manejo de armas, mayores de 12 años, que resultaron seleccionados por sorteo o compensación de sus propietarios ${ }^{28}$ Según Masini se reunieron 710 esclavos que fueron destinados mayoritariamente a la infantería, ${ }^{29}$ representan-

26 Se calcula que fueron 2.080 los movilizados en 1815 sin contar los contingentes enviados de Buenos Aires sobre una población total estimada hacia 1812 de 43.134 pobladores.

27 Oficio del Gobernador Intendente de la Provincia de Cuyo solicitando al Cabildo lista de pardos y morenos libres entre 16 y 50 años de la capital y su jurisdicción, 10/06/1815, Oficio al Cabildo sobre bando que obliga la entrega de esclavos propiedad de europeos españoles, 26/01/1815, DHLGSM, tomo II, págs. 414 y 525 .

28 Interesa advertir las diferencias de valores que ofrecen los registros existentes: frente a un piso mayoritario de $\$ 250$ representado por perfiles de escasa calificación, el valor ascendía a $\$ 490$ para un tonelero o $\$ 450$ para un zapatero o alfarero. Véase la variedad en el valioso apéndice introducido por Masini en su estudio sobre San Luis y San Juan, Masini, José Luis: "La esclavitud negra en San Juan y San Luis. Época independiente", Revista de Historia Americana y Argentina, año IV, núms. 7 y 8, Facultad de Filosofía y Letras-UNCuyo, 1962/1963, págs. 177-210.

29 Aunque el censo de 1812 no distingue entre negros libres y esclavos, ilustra la representación de la "casta" en la composición social de Cuyo antes de la leva. Sobre 8.506 negros registrados en toda la jurisdicción, Mendoza reunía 4.456 (33\% sobre total de la población), San Juan 2.577 (20\%) y San Luis 1.473 (9\%). En síntesis, Mendoza reunía más de la mitad, San Juan el 30\% y San Luis el 16\%. Masini calcula que el total de 4.200 esclavos pudo haberse distribuido del siguiente modo: Mendoza 2.200, San Juan 1.500 y San Luis 500. Cifras que le permiten considerar una representación aproximada de $16,5 \%$ para la capital, 11,5\% para San Juan y 3,1 \% para San Luis. Véase Masini, José Luis: "La esclavitud negra en San Juan y San Luis"... y La esclavitud en Mendoza. Época independient, Facultad de Filosofía y Letras-UNCuyo, Mendoza, 1962. 
do casi la mitad de los libertos integrados en los cuerpos de infantería que arribaron a Chile en 1817.

\section{Solidaridad política en tiempos de guerra}

En 1815 la revolución rioplatense atravesaba severos obstáculos para perdurar: la restauración monárquica en Europa, las derrotas militares en la frontera norte y la expansión de tendencias confederativas en las provincias del litoral y en la misma Buenos Aires, interferidas por el avance de la influencia artiguista, pusieron en evidencia las fisuras del grupo directorial en la ciudad. ${ }^{30}$ Esas tensiones, que precipitaron una crisis de alcance inusitado en Buenos Aires, adquirieron manifestaciones específicas tanto en Cuyo como en Salta en la medida que, a diferencia del escenario porteño, representaban jurisdicciones fuertemente conmovidas por la militarización y el desarrollo de la guerra. La literatura ha considerado esa experiencia como una demostración del ejercicio soberano de los pueblos en el marco de la endeble institucionalidad de las Provincias Unidas del Río de la Plata. ${ }^{31}$ No obstante, un examen pormenorizado de las relaciones políticas ejercidas por Salta y Cuyo con la autoridad establecida en Buenos Aires permite hacer más complejas esas interpretaciones. En este sentido, y aun considerando los rasgos específicos y no necesariamente idénticos, resulta sugerente preguntarse acerca de las formas que asumió esta relación en ambas jurisdicciones en las que la militarización y la guerra operaron de diferente manera.

La caída de Montevideo en poder revolucionario y la recuperación de Chile por parte de los realistas cambió el escenario y las urgencias de la guerra. El ascenso de una facción de los directoriales proclives a disminuir los recursos del plan militar ofensivo organizado por San Martín desde Cuyo precipitó tensiones que culminaron en su desplazamiento y en el nombramiento de un nuevo gobernador a comienzos de 1815. Con ello no sólo se ponía en evidencia la disputa entre facciones de la logia

30 Para un desarrollo pormenorizado de las tensiones facciosas y la división de opinión en la conducción directorial que exhibe la puja entre el sector militar y los letrados o doctores, véase Halperin, Tulio: Revolución y Guerra. La formación de una elite dirigente en la Argentina criolla, Siglo XXI, Buenos Aires, 1979.

31 Chiaramonte, José C.: Ciudades, provincias, Estados: Orígenes de la Nación Argentina, 1800-1846, Ariel, Buenos Aires, 1997; Verdó, Geneviève: ¿Soberanía del pueblo o de los pueblos? La doble cara de la soberanía durante la revolución de la independencia, 1810-1820, Andes 13, CepihaSalta, 2002, págs.145-169. 
Lautarina, más exactamente entre el gobernador cuyano y el director supremo Carlos de Alvear, sino que también se hacía manifiesta la controversia entre quienes en Buenos Aires no consideraban ya imprescindible el mantenimiento de los ejércitos porteños, al considerar escasas las posibilidades de los realistas de sofocar el bastión rioplatense tras haber perdido Montevideo.

La historiografía ha abundado en las demostraciones del "pueblo y vecindario" de la capital cuyana en torno al rechazo unánime de la decisión de los directoriales y la restauración del liderazgo sanmartiniano en el poder local, y ha insistido en ubicar el fenómeno - la "revolución municipal", Mitre dixit - como evidencia objetiva de una vocación "provincialista" contraria a las tendencias centralistas dirigidas desde la capital. Sin embargo, una mirada meridiana de los argumentos vertidos por San Martín así como de los sostenidos por algunos de los oradores del memorable Cabildo Abierto que lo reeligió permite poner reparos a dichas interpretaciones. ${ }^{32}$ En este sentido, San Martín pide licencia no sin antes exponer en oficio al Cabildo que el general realista Mariano de Ossorio preparaba desde Chile una invasión a Cuyo una vez despejado el paso cordillerano. Allí exhortó a "redoblar sacrificios" sobre la base de la "unión y constancia" a favor de la "existencia civil". Después de señalar la necesidad de vencer los obstáculos que dicha empresa suponía, expresaba: "Nuestro primer deber en tales circunstancias es proporcionar a la Capital toda clase de auxilios. Si ésta cae bajo la opresión enemiga como que es la fuente donde emanan los recursos al sostén de nuestra Libertad, o perecerá ésta, ó al menos sufrirá su revés que tal vez no sea dificultoso repararlo". ${ }^{33}$ En otras palabras, la manifiesta lealtad de San Martín a la capital era independiente del momento específico en que el gobierno de las Provincias Unidas aparecía dirigido por la facción alvearista, en cuanto núcleo del sistema revolucionario y sostén de la financiación del ejército insurgente.

Ante la crisis se convocó a los oficiales de la guarnición a una Junta de Guerra que decidió no oponerse a la insubordinación para evitar "una guerra civil" y considerar que el objetivo perseguido era liberar a los "Pueblos de la tiranía" y dejarlos en "plenitud de sus derechos para la elección por medio de sus diputados" de un gobierno legítimo. Idénticos argu-

32 Mitre, Bartolomé: Historia de San Martín y de la Emancipación Sud-Americana, tomo V, Jackson, Buenos Aires, 1950.

33 Documentos para la Historia del Libertador General San Martín, Ministerio de Educación de la Nación, Buenos Aires, 1954, tomo II, 445. 
mentos dirigió a los Tenientes Gobernadores de San Juan y San Luis, y al ayuntamiento capitalino en los cuales el fervor libertario era acompañado de un cuidadoso arbitrio que conllevaba desobediencia a Carlos de Alvear y subordinación a la autoridad de las Provincias Unidas. Ese delicado equilibrio se hizo más evidente en la correspondencia dirigida al todavía Gobernador de Córdoba, en la cual manifestaba que la desobediencia al director supremo no debía eludir la urgencia de sostener la capital por ser "de quien depende el sostén del Cuerpo Social". ${ }^{34}$ La fiel custodia del orden revolucionario se manifestó abiertamente en el Cabildo Abierto (21 de abril), que habría de reelegirlo bajo la unánime opinión de los jefes de la guarnición y la "voz" del Pueblo. ${ }^{35}$

Allí se hicieron explícitas dos opiniones. Por un lado, la encabezada por el cura y vicario Domingo García, regular contrincante de la revolución y de San Martín, que proponía negar obediencia al "actual Gobierno de Buenos Aires" y no prestar una nueva hasta tanto no surgiera un gobierno del "voto unánime de los pueblos" que componen el "Estado"; 36 en oposición a ella, el licenciado Manuel Ignacio Molina adujo que el mismo pueblo que "había negado obediencia y anulado la autoridad del gobierno actual de Buenos Aires, nombrase un nuevo gobernador que lo rigiese, pues el actual debía considerarse desautorizado para seguir en su empleo". Una vez aceptado este argumento, y en medio de protestas que no aceptarían otra autoridad que emanara del actual Gobierno Supremo de las Provincias Unidas, inmediatamente San Martín fue propuesto para desempeñar el cargo con autoridad plena de las cuatro causas, aunque quedaba expresamente manifestado que su continuidad quedaría sujeta al "voto de los demás pueblos que componían la Provincia".

Pero la "Independencia provincial" fue efímera, de tal manera que el mismo día que se celebraba en la iglesia matriz un tedeum para agradecer "al Supremo la destrucción del tirano Gobierno de la Capital", los jefes militares de la guarnición, entre los que se encontraban oficiales arribados desde Buenos Aires y un puñado de líderes que habían conducido la leva

34 De San Martín a Ocampo, 14 de abril de 1815: "Libro Copiador de la correspondencia del Gobernador Intendente de Cuyo", Anales, Facultad de Filosofía y Letras, UNCuyo, 1944, pág. 270.

35 DHLGSM, tomo II, págs. 452-456.

36 En agosto de 1815 San Martín ordena al auditor de guerra Vera y Pintado levantar una información secreta acerca de la conducta del párroco por ser "un indiferente incapaz de cooperar a la propagación del espíritu público a favor de nuestro sistema", Archivo Histórico de Mendoza, Independiente, Carpeta n. ${ }^{\circ} 60$. 
local, ${ }^{37}$ decidieron prestar obediencia al nuevo Director Supremo, el brigadier José Rondeau, y a su reemplazante, Álvarez Thomas, por estar "convencidos de que no podían permanecer por más tiempo las Provincias Unidas sin tener a su cabeza quien girase las negociaciones exteriores, $e$ interiores que estaban paralizadas". La nueva obediencia tenía sin embargo condiciones: la aceptación de la resolución del Cabildo porteño de nombrar sucesor y sustituto se hacía bajo condición expresa de convocar un congreso con representación de los pueblos de las Provincias Unidas con el objeto de transformar el bastión insurgente en una comunidad política soberana e independiente.

En Salta el reconocimiento de la autoridad de Buenos Aires adquirió un perfil diferente a la Cuyana. La intervención de Buenos Aires en Salta tenderá a destruir el poder adquirido por Martín Miguel de Güemes en el transcurso de 1814. Este liderazgo militar, basado en una movilización social e insurreccional muy amplia, introduciría severas reservas para las jefaturas guerreras encargadas de sostener el avance realista y los administradores del poder revolucionario, quienes temían verse obligados a negociar con él para mantener la jurisdicción de Salta en obediencia a la autoridad central de Buenos Aires. La ofensiva del Jefe del Ejército Auxiliar de Perú, respondiendo a las directivas del Director Supremo sobre el creciente poder de Güemes, se materializará a principios de 1815 al otorgarle a José Antonino Fernández Cornejo la tarea de organizar las milicias de Salta, una vez despojado Martín Miguel de Güemes de su cargo militar.

La reacción de Güemes fue inmediata: con el apoyo de las milicias rurales de Salta se autodesignó Coronel Comandante del cuerpo militar de los Paisanos de la Campaña de la Provincia de Salta y por medio de una proclama acusó al Jefe del Ejército Auxiliar de traidor a la causa. Poco después, en una hábil y rápida maniobra enfrentó exitosamente a las tropas realistas en los puestos de avanzada del Ejército del Norte y pasó a Jujuy tomando 600 fusiles pertenecientes al ejército. De inmediato se dirigió a Salta y con sus milicias frente al Cabildo fue designado, en mayo de 1815, Gobernador de la Provincia para luego derrotar militarmente a las fuerzas del ejército del norte, que intentarán sin éxito destituirlo de su cargo. Será

37 Firmaron el acta el Comandante general de armas coronel mayor Marcos González Balcarce, el de frontera Teniente Coronel Don José de Susso, el de Artillería el Capitán Don Pedro Regalado de la Plaza, el Comandante del Batallón n. ${ }^{\circ} 11$, teniente coronel Don Juan Gregorio Las Heras, el del Piquete n. 8 Sargento Bonifacio García, del de Cívicos de Infantería D. Pedro Molina, el de Escuadrones de Caballería Don Javier Correa, DHLGSM, tomo II, págs. 463-464. 
en este momento cuando negociará su lealtad a la revolución de Buenos Aires a través de la firma de un pacto.$^{38}$ A partir de este momento concentrará sus esfuerzos en organizar sus milicias creando, a pesar de la oposición de Buenos Aires, el Cuerpo de Infernales, cuyos oficiales serían designados entre sus hombres de mayor confianza. ${ }^{39}$ Estas fuerzas militares locales que abarcaron la jurisdicción de las ciudades de Salta, Jujuy y Orán contaron con entrenamiento militar, uniforme, el goce permanente de fuero militar y el pago de un salario. El escenario guerrero en el cual se desenvolvieron no excedió, salvo contadas excepciones, los territorios comprendidos por la jurisdicción de la provincia de Salta. La permanente escasez de recursos y el faccionalismo interno impidieron la movilización de esas milicias al distante territorio Alto Peruano..$^{40}$

Pero si es posible observar que la guerra en Salta se sostiene por la acción de Güemes y de sus gauchos - como fueron llamados los paisanos que formaban sus milicias al margen del Ejército Auxiliar estacionado en Tucumán-, también es posible comprobar que dicha acción se inscribe en las guerrillas altoperuanas, para cuyos jefes Güemes es un "padre amante y protector", que los legitima al proponer a Belgrano sus nombramientos como Oficiales del ejército de Buenos Aires. Cuando Güemes le responde a Rondeau aseverando que la libertad en Salta será preservada por sus gauchos y no por el ejército de Buenos Aires, está revelando un proceso de identidad política similar a la evidenciada por Manuel Ascensio Padilla en Cochabamba, al contestar la misiva enviada por el derrotado Rondeau instándole a continuar la lucha por la libertad americana. ${ }^{41}$

Ahora bien, más allá de estas manifestaciones que revelan importantes contrapuntos con las condiciones políticas y militares exhibidas en Cuyo, que remiten de manera inexorable al papel desempeñado por la guerra en el teatro salteño, la designación de Güemes como Gobernador en

38 Este Pacto, conocido con el nombre de los Cerrillos, se firmó en marzo de 1816. Entre sus disposiciones más importantes se encontraban la creación de un ejército en la provincia de Salta, la entrega de 300 reclutas al Ejército Auxiliar del Norte y el compromiso de la provincia de Salta de auxiliar al Ejército de Buenos Aires con “...caballos, reses y cuanto pueda...” Cornejo, Atilio: Historia de Güemes... pág. 195.

39 Mata de López, Sara: "La guerra de independencia en Salta y la emergencia de nuevas relaciones de poder" en Andes, n. ${ }^{\circ}$ 13, CEPIHA, Facultad de Humanidades, UNSa, 2003, págs. 113-143.

40 Mata de López, Sara: "Conflicto social, militarización y poder en Salta durante el Gobierno de Martín Miguel de Güemes” en Herrero, Fabián (comp.): Revolución, política e ideas en el Río de la Plata en la década de 1810, Universidad de Tres de Febrero, Buenos Aires, Argentina, págs. 125-148.

41 Mata de López, Sara: "Salta y la guerra de independencia en los Andes Meridionales" en Jahrbuch für Geschichte Lateinamerikas, 41/2004, Hamburgo, Alemania, 2004, págs. 223-245. 
1815, desconociendo el nombramiento de Hilarión de la Quintana, realizada por Buenos Aires, ¿en qué registro político debe colocarse? ¿Fue un acto de autonomía frente a la capital del ex Virreinato? No es sencillo especular al respecto. ${ }^{42}$ Los argumentos utilizados para justificar esta inédita resolución se basaron en los peligros de nuevas incursiones realistas frente a las cuales Güemes se presentaba como el único jefe capaz de detenerlas por su liderazgo militar. Él y sus partidarios habrán de presentar como imprescindible la necesidad de concentrar el poder para sostener en Salta la guerra de independencia. De todas maneras, es indudable que su designación como Gobernador y la formación de milicias propias constituían un desafío, en razón de su rivalidad con el Director Supremo y con el Jefe del Ejército del Norte, pero es plausible suponer que este desafío estaba dirigido a quienes en esos momentos detentaban el poder en Buenos Aires y que escatimaban su apoyo a Güemes por temor de encontrar en él a un Artigas del Norte. ${ }^{43}$ Avala esta hipótesis sus expresiones a favor de la unión de las provincias del Río de la Plata y el deseo de conciliación con Buenos Aires a pesar de actuar desconociendo sus mandatos. En los momentos más álgidos de su enfrentamiento con Rondeau, en un oficio que eleva al Director Supremo justificando la necesidad de retener las armas que ha tomado del ejército en Jujuy, se pregunta preocupado "¿Cuándo llegará el suspirado día, en que veamos reunidos nuestro Congreso, y que compuesto de sabios, y virtuosos, formen una Constitución libre, dicten sabias leyes y transigan las diferencias y relaciones de las provincias? Este será el término de la revolución; porque cuando la soberanía está repartida en todos, no puede haber, ni orden, ni leyes, ni gobierno, ni libertad, ni soberanía, sino una anarquía y una interminable guerra civil". ${ }^{44}$

En suma, las experiencias políticas que ambos espacios han exhibido en relación con el gobierno central en el curso de 1815 ponderan el protagonismo de las milicias, las jerarquías guerreras edificadas en relación con

42 Desde 1810 los gobernadores de la Provincia de Salta habían sido designados por Buenos Aires, sin que se registrara oposición local. Es indudable que el Cabildo, al designar a Güemes, desconoció la autoridad de Buenos Aries para imponer Gobernador.

43 En un Oficio el Directorio le ordena al Jefe del Ejército Auxiliar, que extreme sus cuidados y sofoque cualquier discordia “...para no ser envueltos en las desgracias que por iguales principios lamentamos hoy en la Banda Oriental” y le sugiere “...debilitar la fuerza de gauchos que ha obrado hasta ahora con las tropas de lineas sobre Salta y Jujuy alejando honestamente a los caudillos que las han conducido". Borrador de Oficio del Gobierno a Rondeau, Buenos Aires, 15 de octubre de 1814, en Güemes Documentado, Editorial Plus Ultra, Buenos Aires, 1980, tomo 2, págs. 301-303.

44 Oficio de Güemes al Director. Salta, septiembre 25 de 1815, en Güemes documentado, Plus Ultra, Buenos Aires, 1980, tomo 3, pág. 29. 
ellas y el uso estratégico de las instituciones representativas urbanas como baluarte de legitimación política frente al alvearismo y la crisis desatada en la capital. Es necesario distinguir sin embargo las modalidades de esa lealtad exhibida tanto por la Provincia de Cuyo como por la de Salta. En el caso cuyano tendrá mayor peso sin duda la jerarquía y disciplina militar que incluye a jefes, oficiales y tropa, mientras que en Salta serán las milicias y su movilización de cara al peligro realista las que tendrán un peso decisivo en este proceso de desobediencia y lealtad. Con todo, la reunión del Congreso Soberano y la declaración de la independencia de las Provincias Unidas del Río de la Plata (1816) constituyó un acto soberano que reafirmaba la legitimidad revolucionaria en una geografía política que se sostenía en un esquema centralista del poder con sede en Buenos Aires e incluía entre otras a las Provincias de Cuyo y Salta.

\section{Guerra e identidades políticas}

El recorrido trazado por la revolución y la militarización que habría de sostenerla se extenderá durante más de una década. La guerra constituirá un factor decisivo en el proceso de configuración de identidades políticas de indiscutible protagonismo en la resolución de la independencia y la construcción de los estados nacionales a mediados del siglo XIX.

$\mathrm{Si}$ en el desplome del imperio español la pertenencia americana fue esgrimida por los movimientos independentistas, la clausura de la guerra la pulveriza. Abordar este proceso nos remite a la consideración de tres núcleos problemáticos. En primer lugar, es necesario atender al sentido de pertenencia e identidad americana en el cual se reconocían las elites letradas que protagonizaron la revolución inaugurada en Buenos Aires; en segundo lugar, es conveniente señalar que la revolución redefine la categoría de americano en la medida en que ya no se limita a los nacidos en tierra americana; finalmente, se debe advertir la incidencia de las antiguas jurisdicciones borbónicas que en algunos casos los procesos revolucionarios terminan por fragmentar — como es posible observar con el Virreinato del Río de la Plata - mientras que, en otros - como en el antiguo reino de Chile-, se verá robustecida. Intentar dar respuesta exhaustiva a estos problemas no es una tarea que podamos abordar en el presente artículo. Esa limitación, sin embargo, no impide llevar a cabo algunos ejercicios sucesivos que servirán para examinar en qué medida la prolongación de la gue- 
rra, sus formas e incluso la exigencia de desplazamientos imprimieron direcciones en ocasiones inesperadas que favorecieron la matización y sedimentación de la genérica identidad "americana" de la cultura política disparada con las revoluciones de independencia.

Como toda una literatura ha señalado, la ingente movilización de hombres y recursos exhibida en el amplio espacio rioplatense y sudamericano se convirtió en una de las novedades más relevantes introducidas por la guerra. La formación de cuerpos armados estables y profesionalizados representó una experiencia relativamente inédita a partir de la cual no pocos varones reclutados - voluntaria o coactivamente-, al convertirse en actores políticos de importancia, llevaron a cabo trayectorias sociales y políticas insospechadas. Si la carrera de la revolución propició sobre todo la conformación de nuevas elites, para la mayoría de los enrolados en los ejércitos patriotas la guerra los condujo a regiones distantes del lugar en que habían nacido u organizaban su vida cotidiana. Esa experiencia de movilidad espacial, o el "viaje" en el sentido atribuido por Anderson, ${ }^{45}$ adquirió particular visibilidad ante los contrastes o éxitos militares que imponían a los derrotados el castigo del destierro o el camino de la emigración. Este último fenómeno sería puesto en evidencia por José Antonio de Moldes, un exponente salteño de la revolución rioplatense, tras ser rechazado en 1816 como Congresal en Tucumán. Decepcionado escribió: "Dispersos, emigrados, errantes, aún no sabemos la Patria que hemos de vivir"

La experiencia a la que aludió Moldes fue moneda corriente en el desarrollo de la guerra y cruzó a las mismas elites revolucionarias. Un caso particularmente rico del tejido de tensiones que alimentaban las divisiones facciosas en los baluartes australes del antiguo imperio español aparece representado por las situaciones producidas a raíz de la reconquista del reino de Chile (1814) por las fuerzas invasoras dirigidas desde Lima por el Virrey Abascal que, a juicio de la literatura, "peruanizó" el conflicto. ${ }^{46} \mathrm{El}$ éxito militar de los realistas pretendió reencauzar el poder y la administración a la autoridad de Lima y de la Monarquía, a través de la frustrada

45 Anderson, Benedict: Comunidades imaginadas. Reflexiones sobre el origen y la difusión del nacionalismo, Fondo de Cultura Económica, México, 1993, capítulo 4.

46 Sobre la revolución de independencia en Chile, véase especialmente Eyzaguirre, Jaime: Ideario y ruta de emancipación chilena, Editorial Universitaria, Santiago, 1957; Donoso, Ricardo: Las ideas políticas en Chile, Eudeba, Buenos Aires, 1970; Villalobos, Ricardo: Tradición y reforma en 1810, Ediciones de la Universidad de Chile, Santiago, 1961, y Jocelyn Host-Letelier, Alfredo: La independencia en Chile. Tradición, modernización y mito, MAPFRE, Madrid, 1992. 
negociación o tratado de Lircay y algunos apoyos locales, asimismo la política dirigida a controlar a los "insurgentes" o "revolucionarios" trajo como consecuencia destierros y emigraciones de notable impacto ${ }^{47}$ La historiografía suele acentuar la reconquista como expresión del giro absolutista posterior al regreso de Fernando VII menguando las posibilidades de complejizar la experiencia política en Chile. Es preciso señalar, por ejemplo, la pretensión del general invasor de indultar a una buena parte de los revolucionarios (que fueron desterrados a la isla de Juan Fernández o a haciendas distantes de la capital), así como la instrumentación de una política de exterminio para liquidar la influencia de los fugados o "facinerosos" que habían pasado a Cuyo por los cruces cordilleranos. ${ }^{48}$

En la crítica retirada y en la dispersión de las tropas patriotas chilenas frente al acecho del ejército realista después del enfrentamiento en Rancagua, vastos contingentes de varones, mujeres y familias enteras cruzaron la cordillera de los Andes con el fin de refugiarse en Cuyo; sin embargo, las tensiones facciosas, que atravesaban a los emigrados en relación al proceso político previo y al desempeño guerrero en la resistencia contra el ejército realista, aumentaron las diferencias entre José Miguel Carrera y Bernardo de O'Higgins. De cara a ambos liderazgos, y en función de sociabilidades políticas comunes ${ }^{49}$ el gobernador San Martín optó por el segundo y exigió a Carrera el reconocimiento de su autoridad apoyado por el gobierno central de Buenos Aires. ${ }^{50}$ En efecto, la evidencia empírica disponible - que jalona un violento intercambio de oficios- permite restituir con nitidez la exigencia impuesta al caudillo chileno con respecto a las órdenes emanadas por una autoridad política local sostenida por las leyes y gobierno de las Provincias Unidas: el 30 de octubre San Martín publicó un bando por el cual daba cuenta de la difícil situación

47 Barros Arana, Diego: Historia general de Chile, Editorial Universitaria, Santiago, 2000; Vicuña Mackenna, Benjamín: El ostracismo de los Carreras, Imprenta del Ferrocarril, Santiago, octubre 1857 .

48 Archivo General de Indias- Chile 207 y 208; Diversos 4 y 5.

49 La confluencia de americanos en sociedades secretas en Cádiz y en Sevilla ha sido uno de los tópicos más reiterados para explicar las solidaridades políticas a favor de la independencia como requisito previo a la incorporación en las dinámicas revolucionarias hispanoamericanas. Véase a modo de ejemplo Cánter, Juan: "Las sociedades secretas y literarias", Historia de la Nación Argentina (desde los orígenes hasta la organización definitiva en 1862), Academia Nacional de la Historia, El Ateneo Editorial, Buenos Aires, 1961.

50 La opción sanmartiniana fue argüida por Mitre y desde entonces no ha sido reinterpretada. Véase a modo de ejemplo, Raffo de la Reta, J.C.: El General José Miguel Carrera en la República Argentina, La Facultad, Buenos Aires, 1935, y Pérez, Joaquín: San Martín y José Miguel Carrera, Facultad Eva Perón, Buenos Aires, 1954. 
vivida por los chilenos caídos en desgracia en defensa de la "causa de la libertad", aunque los prevenía de que en "esta Provincia no existe ni puede existir más autoridad que la constituida por el mismo supremo Director"; dicha política fue validada por el gobierno en Buenos Aires que juzgó como delirio la pretensión de Carrera de sostener una autoridad independiente "en nuestro territorio". ${ }^{51}$ Por consiguiente, la resolución del conflicto permite visualizar la manera en que el argumento esgrimido por el gobierno de las Provincias Unidas enfatiza una estrecha relación entre territorio y soberanía.

El gobernador dispuso abastecimiento y asilo para los emigrados, y propuso disminuir el ascendiente de José Miguel Carrera, hechos que provocaron desórdenes y disturbios entre la tropa: ${ }^{52}$ en noviembre O'Higgins daba aviso de la fuga de tres soldados armados que, a su juicio, seguramente habían seguido "el mal ejemplo de los Carrera" quien auspiciaba pasarse incluso al enemigo "antes que servir bajo las Banderas de Buenos Aires". ${ }^{53}$ Frente a la amenaza que suponía la existencia de tropas divididas en torno a jefaturas de origen con severas dificultades de conducción, y la sospecha de que el estado de "fermentación" de las tropas chilenas atentaba contra el orden público, el gobierno no sólo ajustó los términos de la protección a los "desgraciados chilenos", sino que debilitó las bases del liderazgo de Carrera y sus aliados, a través de acuerdos e invitaciones realizadas a sus seguidores, que en varios casos no tardaron en integrar el cuerpo de oficiales y la tropa. La potestas sanmartiniana fue más contundente con los que mantuvieron lealtad al caudillo chileno hasta el último momento. Frente a ellos, el gobernador cuyano llevó a cabo una agresión directa contra el convento donde se alojaban jefes y tropas leales a Carrera quienes, en abrumadora mayoría, pasaron a engrosar las filas de los regimientos en formación. La política frente al caudillo chileno caído en desgracia y los pocos seguidores que consiguió mantener fue completada con el traslado en un primer momento a la vecina localidad de San Luis y posterior-

51 "Libro Copiador de la correspondencia del Gobernador Intendente de Cuyo", Anales, Facultad de Filosofía y Letras, 215.

52 Considerar las condiciones a las que estaban expuestos los emigrados en Mendoza daría lugar a otro trabajo. Sólo indicaremos aquí que la manutención de los mismos dependió de los aportes particulares y de la obligación de conchabarse como contraparte de habitación y alimentos. Entre 1817 y 1823 abundan los pedidos ante las autoridades locales para obtener protección. Archivo Histórico de Mendoza - Época Independiente, Legajos 497, 9, 11ª , 58, 59, 41.

53 "Libro Copiador de la correspondencia del Gobernador Intendente de Cuyo", Anales, Facultad de Filosofía y Letras, 219. 
mente a Buenos Aires por orden del directorio. A partir de entonces, la acción carrerina pasaría a engrosar el inestable elenco de opositores de los "tiranos" - esa categoría o concepto era asimilada a las jefaturas políticas y guerreras de los grupos insurgentes proclives a los formatos centralistas opuestos a los confederativos-, adquiriendo después de 1818 su punto culminante cuando fueron pasados por armas dos de los hermanos Carrera en la ciudad de Mendoza por las autoridades leales al esquema de poder de los martinianos. ${ }^{54}$ En suma, el fenómeno de emigración política chilena permite sugerir un proceso de diferenciación política que fortalece la posición del gobernador y de la red de gobiernos sólidos que lo sostenía en la cúspide del poder local, como también invita a conjeturar la delimitación de una frontera política dirimida en relación con jurisdicciones previas que fueron robustecidas por los desiguales procesos revolucionarios llevados a cabo a uno y otro lado de la cordillera.

Podría argumentarse que el conflicto antes expuesto nos enfrenta a un fenómeno de ningún modo obviado, sino enfatizado por la literatura para evaluar el dilema de la diferenciación política en pleno desarrollo de la guerra de independencia. En efecto, no resulta para nada sorprendente evaluar el peso de los procesos históricos e incluso revolucionarios en los márgenes australes del "imperio sublevado". No obstante, a pesar de una conformación relativamente temprana de identidades políticas fieles a las antiguas jurisdicciones borbónicas, las revoluciones que tuvieron lugar a partir de 1810 estuvieron lejos de diluirlas, imprimiendo una dirección oblicua a la vocación americana de sus más esclarecidos promotores. Esas identidades opuestas parecen haberse puesto de manifiesto sobre todo en los ejércitos patriotas después de derrotar a las fuerzas realistas en los enfrentamientos armados de Chacabuco (febrero 1817) y Maipú (abril 1818) en territorio chileno. Las disidencias entre los oficiales de batallones y regimientos allí coaligados se hicieron patentes durante 1818 , en plena marcha de la reconquista de los territorios del sur aún controlados por realistas. Conviene recordar que el avance sobre Chile del ejército, organizado bajo la égida del gobierno de las Provincias Unidas, había integrado una porción de oficiales emigrados de la denominada Patria Vieja, abrumadoramente vinculados

54 El conflicto dio lugar a una profusa literatura en el marco de la constitución de las historiografías decimonónicas. Véase un análisis del juicio y del contexto normativo y político en Bragoni, Beatriz: "Justice révolutionnaire. Morphologie du procès criminel des frères Carrera pendant les guerres des indépendances hispano-americaine (1818)", Annales. Histoire, Sciences Sociales, Paris, en prensa. 
a la facción liderada por O’Higgins y, en menor proporción, por aquellos que hasta octubre de 1814 habían reconocido a José Miguel Carrera como jefe político y militar del sector patriota chileno. Una vez conformado el gobierno independiente en Chile, encabezado por O'Higgins, la nueva administración vio conveniente fortalecer los lazos de pertenencia entre oficiales chilenos y, a través de ellos, a las tropas movilizadas integradas ahora en una renovada pirámide guerrera. Ese estímulo que trazaba una línea que priorizaba el lugar de nacimiento y no el mérito en el desempeño guerrero acarreó complicaciones.

Un primer chispazo tuvo origen en los premios concedidos a oficiales del "ejército de Chile" y "no al de los Andes" por su acción en la memorable batalla de Maipú, distinción que fue reclamada de inmediato ante el gobierno de Buenos Aires que autorizó su uso a los "beneméritos" del ejército sanmartiniano que hubieran prestado servicios en aquella acción..$^{55}$ Poco después el gobierno chileno habilitó el uso de un escudo "con fondo celeste" a los jefes y oficiales del ejército de los Andes que acompañaron al general chileno Freire en la exitosa campaña del sur. No obstante, el otorgamiento de la distinción estuvo lejos de limar asperezas entre oficiales y tropas de ambas formaciones militares estacionados en el corazón de Santiago. En oficio del 9 de noviembre de 1818 San Martín se hacía eco de la representación dirigida por el sargento mayor Manuel Acosta, que impugnaba la asignación de medallas de la Legión del Mérito de Chile para ser elevada al Director del Estado, amparado en la antigüedad del cargo y permanencia en el servicio militar. ${ }^{56}$ El reclamo, si bien ponía en evidencia la irritación producida por la maniobra orquestada por integrantes del Estado Mayor, estaba destinado a frenar el malestar presente en las tropas en la tarde el 11 de diciembre cuando los soldados negros de los batallones $7 .^{\circ}, 8^{\circ}$ y $11 .^{\circ}$ protagonizaron un tumulto que terminó en la fuga de un puñado de ellos y en una cruenta represión y control. ${ }^{57}$ Una vez controlado el conflicto a través de disposiciones variadas, se ordenó la

55 Oficio del Ministro de Guerra, Matías de Irigoyen, a Antonio González Balcarce, Buenos Aires 04/12/1818, DHLGSM, tomo IX, pág. 316.

56 A fin de que recaiga la providencia que conceptuare de justicia en un asunto que, siendo tan delicado por su naturaleza, requiere la circunspección del Gobierno por política y por justicia. Por la primera, porque es la legión creada a favor del mérito un estímulo de las acciones virtuosas mucho más apreciable que las remuneraciones en dinero, y para la segunda porque no deben confundirse el mérito oficioso y productivo con la inacción artificiosa y estéril siempre fecunda de tramoyas y de sorpresas para gozar de las apariencias de la virtud DHLGSM, tomo IX, pág. 340.

57 DHLGSM, tomo IX, págs. 341-342 y 350. 
lectura de una proclama durante tres días sucesivos. Allí se hacía eco de las disputas habidas entre los soldados de los ejércitos "al extremo de haberse batido con piedras y palos en número considerable" por lo que amparado en las facultades obtenidas de ambos supremos gobiernos de Chile y Buenos Aires, se dispusieron sanciones por pelea entre dos o más de tres soldados de diferentes cuerpos, al tiempo que se procuró subsumir diferencias entre los "soldados del ejército unido" a través de una encendida arenga patriótica y libertaria: "nuestros enemigos procuran inducir la discordia, ya que no pueden triunfar con las bayonetas: no lo conseguirán [...] Vuestro General os encarga la Unión, y fraternidad entre todos: él espera que así se verifique, y yo os amonesto como vuestro Padre; pero creed que al que faltare se le castigará con una severidad inflexible. Soldados viva la Patria". ${ }^{58}$

Es probable que las fricciones producidas por episodios de este tipo representen evidencias débiles para proponer, a partir de ellas, diferencias sustantivas entre oficiales y tropa reunidos en las filas del ejército Unido. No obstante, y aun aceptando los riesgos de dispersión o disolución de los cuerpos armados en aquel momento exiguo de recursos para aprovisionar y mantener batallones y regimientos estacionados en Santiago, y para cuando el gobierno chileno destinaba sus caudales a fortalecer la escuadra naval destinada a asegurar la extensa línea marítima, la apelación patriótica americana no eludía, sino que reconocía la unidad de ambos ejércitos, adquiriendo manifestaciones simbólicas y discursivas distintivas. Esa integración diferenciada se puso en evidencia en las tres banderas destinadas a distinguir las operaciones militares que debían iniciar la expedición a Perú: las "Instrucciones reservadas que debían observar los jefes de cada cuerpo en caso de batalla" se referían concretamente al pabellón tricolor que identificaba al Estado de Chile, el bicolor de las Provincias Unidas y uno rojo que unía a todos bajo el significado de "Viva la Patria". ${ }^{59}$ En conexión con esto, las proclamas reconocían diferentes interlocutores: al momento de idear el conocido repaso de la cordillera por el ejército a su mando (integrado en su mayoría por jefes y oficiales del Ejército de los Andes y dos mil chilenos), San Martín dirigió tres proclamas, una al ejército de los Andes, otra al de Chile y una tercera a los "individuos del Ejército Unido".

58 Proclama de San Martín, DHLGSM, tomo IX, págs. 354-355.

59 Galván Moreno, C.: Bandos y proclamas de San Martín, Editorial Claridad, Buenos Aires, 1942, pág. 35 
¿En qué medida la restitución de esta cadena de indicios permite reinterpretar las identificaciones políticas en los ejércitos de la independencia? Ensayar algún tipo de respuesta al dilema supone ubicar la experiencia guerrera en las coordenadas del vector patriótico americano que había amalgamado su conformación, y las precarias entidades políticas ya independientes que sostenían las formaciones militares a las cuales debían obediencia o lealtad sobre la base de una relación eminentemente contractual por la cual el incumplimiento de las obligaciones del Estado habilitaba a los enrolados a no cumplir con los suyos. ${ }^{60}$ Aun reconociendo la ambigüedad de esos vínculos, y las complejas direcciones que podían llegar a alcanzar en un escenario cargado de incertidumbres, el desempeño guerrero representó quizá una de las pocas prácticas políticas homogenizadoras capaz de uniformizar sensibilidades patrióticas y/o políticas colectivas en torno a las inestables $\mathrm{y}$, de ninguna manera predeterminadas, comunidades políticas soberanas. Al preguntarse cómo las unidades administrativas hispanoamericanas pudieron llegar a ser concebidas a través del tiempo como patrias, Benedict Anderson propuso "examinar las formas en que los organismos administrativos crean significado" postulando el papel del viaje o de la peregrinación como experiencia imaginaria potente de "creación de significados". ¿A qué imágenes nos enfrentan los itinerarios errantes de los guerreros del ejército de los Andes? Que esa estructura de experiencia resultó eficaz a la creación de lazos políticos e identitarios comunes da testimonio el memorial del teniente coronel José María Aguirre al momento de justificar su retiro del ejército de los Andes en 1822. Después de trazar una genealogía guerrera iniciada en 1815, el veterano oficial juzgaba que los

60 La naturaleza del contrato que forjaba el vínculo entre el Estado y el soldado se desprende de las sumarias y juicios por deserción en el ejército de los Andes. En 1815, el defensor nombrado del soldado Pelestay argumentó: "Es muy sabido que todo Soldado desde el momento en que tomó Plaza celebra un recíproco contracto con el Estado en que éste le ha de subministrar pan, prest y vestuario, bajo este supuesto espontáneamente se obliga a servir, se sujeta a las Penas de la Ordenanza y, lo que es más, su misma libertad en cierto modo lo esclaviza: así es que si se le falta a estas condiciones, o pactos él tiene un derecho para no cumplir los suyos, y si ha exigido recompensa en su trabajo, y no la ha conseguido puede muy bien abandonar a quien no cumple lo que contracta, así como éste tiene un derecho a expulsarlo de su servicio si no le sirva con la actividad voluntad y honradez que contrató. De las declaraciones tomadas a los testigos, y dadas por Pelestay se patentiza no haber sido éste socorrido con el vestuario que le pertenecía ni mucho menos con el Prest contratado; con que claro está que si se le ha faltado a lo pactado no puede caer sobre él la Pena impuesta por la Ordenanza, máxime cuando consta de la Confesión de él haber sido siempre reputado como Recluta y haber sido muy poco instruido en las leyes penales. El Ayudante Mayor de Plaza y juez fiscal de la Comisión Militar reforzó el argumento: "No me atrevo a pedir la pena ordinaria... en razón de la falta de sueldos que ha sufrido, y muy particularmente la del vestuario". AGPM- Independiente, 442, 4. 
premios otorgados por la exitosa campaña de Perú no habían hecho justicia "a las privaciones y el honor del pabellón argentino". ${ }^{61}$ Con ello Aguirre disparaba contra el núcleo del sistema de intercambios previstos entre formaciones militares compuestas por sucesivas y diferentes presiones reclutadoras en el interior de poderes y jurisdicciones en constante configuración: "admírese vuestra señoría al contemplar el resultado, que el premio de tantas fatigas había de ser privarlos de pertenecer a su patria". El desencanto de Aguirre aludía a lo sucedido en Huaura cuando frente al intento de otorgar a los oficiales "despachos como oficiales del Perú", tuvo la "firmeza de devolverlos al excelentísimo señor capitán general; diciéndole que había sido equivocación de secretaría, y fueron extendidos de nuevo como de las Provincias Unidas". Una vez concluida la campaña el problema volvió a suscitarse, adquiriendo para Aguirre proyecciones insospechadas:

[...] rendidos los castillos del Callao, fui prevenido por el protector del Perú don José de San Martín, de que el batallón de cazadores de mi mando debía ser un cuerpo del Estado del Perú. Yo no trepidé en contestar que mis oficiales y aun los soldados, no querían renunciar [a] su patria; pero se me dijo que el que tuviera marquesado en su país, que lo fuese a disfrutar, y el que no lo tuviese cargase la escarapela del Perú [...] Con esta intimidación, aunque yo no era marqués, ni tenía más vínculo que mi honradez y mi espada, tomé el prudente partido de dejar el mando del cuerpo; y seguidamente se hizo saber en la orden general que el batallón de cazadores pertenecía al ejército del Perú. [...] Yo siempre esperaba que algún día el excelentísimo gobierno reclamaría de esa arbitrariedad, porque no hay más que ver los despachos de los oficiales fundadores del cuerpo y la fecha en que se dieron para convencerse de que no pudo en modo alguno pertenecer al Perú, pues fue creado antes que existiese autoridad alguna constituida en aquel país y compuesta su base de oficiales y tropas del Estado argentino, y aunque después hubiese sido aumentado con recluta de peruanos, ésos se deben contemplar en reemplazo de los muertos e inútiles en el servicio del mismo Estado, el cual está en la obligación de reintegrar el total de la fuerza que se introdujo para su libertad.

En ese fascinante ejercicio de memoria política, el veterano guerrero de la independencia introducía un registro de identificación afirmado en una entidad política inexistente, que obraba como principio imaginario decisivo de su perfil de soldado edificado en el periplo difuso de la patria, aunque con severas dificultades para ser transferido de manera mecánica a

61 El Memorial fue confeccionado en Mendoza el 2 de diciembre de 1822 y fue reproducido en la obra que el general Espejo dedicara al Paso de los Andes, Biblioteca de Mayo. Colección de Obras y Documentos para la Historia Argentina. Guerra de la Independencia, tomo XVI, Primera Parte, Buenos Aires, 1963, 14199-14200. 
otra autoridad o "Estado". Para Aguirre esa transferencia era incompresible en la medida que torcía o desviaba la naturaleza del vínculo originario que aparecía constituido en una experiencia colectiva ensayada en el interior y exterior de la unidad político-administrativa a la cual estaba convencido de pertenecer. Tres años después, en 1825, Aguirre daría a conocer un Compendio de las campañas del ejército de los Andes en el que reparaba en el "destino glorioso del pueblo argentino" por ser llamado a combatir la "tiranía en América", en la integración de reclutas de diferentes provincias y en el carácter "liberal y generoso" de sus oficiales y tropas al sostener la independencia de Chile y no operar como conquistadores.

El derrotero militar del Ejército Auxiliar de Perú presentó sustanciales diferencias con el del Ejército de los Andes. Prácticamente inactivo a partir de 1816 tras sufrir su tercera derrota en territorio altoperuano, desapareció en 1820 al involucrarse en las luchas intestinas de las Provincias Unidas. La guerra que tuvo lugar en ese espacio andino, al igual que en la Provincia de Salta, tendrá como protagonistas a las milicias organizadas por Güemes a las cuales se sumaban voluntarios en momentos de peligro o cuando se aproximaban las huestes realistas.

Las derrotas del ejército porteño desplazaron hacia Salta en calidad de emigrados a quienes en las provincias altoperuanas habían apoyado de manera manifiesta la revolución de Buenos Aires. A diferencia de lo sucedido con los emigrados chilenos, no presentaron liderazgos sólidos que plantearan conflictos serios en relación con la autoridad detentada por Güemes. Algunos de ellos prefirieron ubicarse políticamente con el Teniente de Gobernador de la ciudad de Jujuy, opositor al Gobernador de la Provincia de Salta, mientras otros se sumaron a su grupo más cercano. Desempeñaron en cada caso un importante papel las relaciones de amistad, negocios y parentescos establecidos desde épocas coloniales, pero no es desacertado pensar en la posibilidad de diferenciaciones políticas, aunque para ello sería preciso ahondar más sobre el tema. Resulta llamativo incluso observar que no operaron, al menos abiertamente, en la disputa de poder entablada entre Güemes y el Director Supremo.

En su estancia en Salta participaron, sin embargo, en diferentes instancias políticas. En 1815, cuando el Gobernador Martín Miguel de Güemes se enfrentó con el Jefe del Ejército Auxiliar de Perú, el Cabildo dispuso convocar "[...] a todas las corporaciones del pueblo, vecinos de él sus habitantes y moradores, con los emigrados de las provincias del Alto Perú" a fin de darles a conocer los graves acontecimientos que podrían 
desembocar en una guerra civil. ${ }^{62}$ Esta representación política adquirió mayor importancia cuando estos emigrados procedieron a elegir en Salta, según lo establecido por las normativas dispuestas por el gobierno de las Provincias Unidas, a los diputados que representarían a las Provincias altoperuanas en el Congreso Soberano que sería celebrado en Tucumán en 1816. La solidaridad política manifestada en esta instancia revela la existencia de propuestas políticas tendentes a propiciar una organización política respetuosa de los derechos territoriales asignados por la administración borbónica a la que fuera capital del Virreinato del Río de la Plata. La nación cuya declaración de independencia se concretaba en 1816 era concebida por los revolucionarios altoperuanos residentes en Salta —al igual que por la mayoría de los representantes allí presentes- como el conjunto de provincias y pueblos que habían integrado el Virreinato, respetando así la tradición política centralista heredada de los borbones.

Los emigrados altoperuanos en Salta no fueron sólo miembros de la elite o funcionarios que propiciaron el reconocimiento a la Junta de Buenos Aires o quienes apoyaron posteriormente a los "insurgentes porteños". Entre ellos se encontraban jefes de milicias y milicianos que siguieron al derrotado Ejército Auxiliar de Perú y que no tardaron en incorporarse al cuerpo de milicias organizada por Güemes, lo cual constituyó un indicio de la comunidad de intereses compartidos y fraguados al calor de la resistencia contra las tropas realistas. Representaba asimismo un reconocimiento a la autoridad de Buenos Aires en tanto Martín Miguel de Güemes era - además de Gobernador de Salta— el Jefe de la Vanguardia del Ejército porteño.

Las guerrillas altoperuanas al igual que las milicias en Salta identificaron a las tropas realistas con los opresores contra cuyo mal gobierno se hacía preciso luchar, acorde con una cultura política heredada de la colonia. Pero también peleaban según sus propias expresiones por la "patria" y por la "libertad". Corresponde sin embargo preguntarse qué sentido adquiere para estos hombres la palabra libertad. ¿De qué manera comienza a vincularse a la patria, el lugar donde se ha nacido, el lugar propio, con los jefes del Ejército de Buenos Aires adquiriendo de este modo perfiles políticos diferentes? Estas preguntas, si bien ineludibles, resultan difíciles de responder.

Es indudable que además de la guerra y junto con ella los bandos, las proclamas, las arengas, a las cuales se hallaban sometidos de manera constante, cumplieron un importante papel en el sentido político atribuidos a

62 Acta del Cabildo de Salta del 13 de marzo de 1816, en Plus Ultra, Buenos Aires, 1980, tomo 3, pág. 290. 
patria y libertad. También los periódicos y los panfletos contribuyeron en la construcción de una cultura política en sectores sociales que incluían desde comunidades indígenas, mestizos, esclavos y criollos cuyo denominador común era su analfabetismo. Es importante no descuidar la importancia de la oralidad en estos contextos sociales y tampoco considerar los discursos políticos tan solo desde el lugar del enunciador, en este caso las elites dirigentes del proceso revolucionario. ${ }^{63}$ De cualquier modo, es seguro que un cúmulo de intereses y expectativas se entrecruzan con imaginarios políticos diluidos en la marea revolucionaria que los articula operativamente en los discursos de la elite dirigente.

Junto a este proceso dinámico y complejo de identificación, en el cual el enfrentamiento con el "otro" comienza a ser percibido en términos políticos, el curso de la revolución y el éxito o fracaso de las armas forjaron otros dilemas. En Salta, el principal sería el de sostener adecuadamente a una proporción importante de hombres permanentemente movilizados y conservar la adhesión a la causa revolucionaria de los sectores propietarios sobre los cuales habrá de caer todo el peso del mantenimiento de la guerra. Pero si los empréstitos y las donaciones establecidas por el gobierno de Güemes gravaban seriamente los patrimonios, enajenando el favor de la elite, a los hombres movilizados, en su mayoría peones, arrenderos y agregados de estancias y haciendas de la jurisdicción les resultaba molesto e injusto cumplir con sus tareas rurales y en especial pagar los arriendos y prestar servicios a los dueños de las tierras que usufructuaban. Ellos, tal como lo proclamaba Güemes, habían "defendido con heroicidad la gran causa de nuestra independencia" ${ }^{44}$ en tanto que los propietarios "...viven en el descanso y comodidad de su casa..." ${ }^{65}$. Obviamente esperaban reconocimiento y gratitud, es decir, posibilidades de obtener cargos en las milicias y beneficios materiales.

La falta de dinero se acentuó a partir de 1816 con la pérdida definitiva del control militar y político sobre las ciudades altoperuanas y por ende de la producción minera de Potosí y Oruro. Las relaciones entre la elite de Salta y las milicias comandadas por el Gobernador Güemes se deterioraron aún más a medida que las milicias apelaron con mayor violencia y frecuen-

63 Glave, Luis Miguel: La república instalada. Formación nacional y prensa en el Cuzco 1825-1839. IFEA-IEP, Perú, 2004.

64 Oficio de Güemes al Cabildo de Salta, agosto de 1815, AGN, Sala C. 5.7.4- Gobierno de Salta- 1814-1818

65 ABHS. Informe del Comandante D. Luis Borja Díaz al Gobernador José Ignacio de Gorriti, mayo de 1822, Armario Gris. 
cia al saqueo. La disciplina en esas tropas mal pagadas o directamente carentes de cualquier otra retribución que no fuere el desconocimiento de los derechos de sus patrones y la protección de sus jefes inmediatos representaron una amenaza no sólo para la elite sino también para el propio Güemes y sus oficiales obligados permanentemente a negociar y conceder para conservar espacios de poder y autoridad, en un complejo contexto de alianzas y traiciones.

En el Alto Perú, las guerrillas rurales continuarán hostigando a los realistas, a pesar de las importantes derrotas que sufrieron durante 1816, año en que murieron los principales líderes de las mismas. La relación de Güemes con los jefes de estas guerrillas, sus esfuerzos por reorganizarlas y darles una dirección, proponiendo nombramientos de oficiales, resultan indicativas de la necesidad de estos movimientos insurgentes de contar con apoyo y legitimación política y militar. Implica asimismo el reconocimiento de una autoridad supra local.

Pero si en Salta fue necesario recurrir cada vez con mayor frecuencia a las confiscaciones y a los empréstitos, en el Alto Perú los saqueos fueron prácticamente la principal fuente de abastecimiento. La guerra se transformó en una guerra de recursos de la cual participaron no sólo los insurgentes sino también las tropas realistas. No pocas incursiones en territorio salto-jujeño y en Tarija por parte del Ejército del Rey respondieron a la necesidad de abastecerse. Un vecino de Jujuy expresa con claridad en una carta que son igualmente nefastas las incursiones de los realistas que las de los patriotas. Ambas acaban con el ganado y las sementeras. ${ }^{66}$

De esta manera, la interrupción del comercio, la falta de pago de los arriendos por parte de los milicianos, la entrega obligada de ganado y el saqueo fueron minando en Salta el apoyo al Gobernador. A la oposición política, que evidentemente existía, y sobre la cual es preciso indagar más, se agregaban los costos del sostenimiento de la guerra, la ruina del comercio con el Alto Perú y, en algunos casos, la quiebra de comerciantes de efectos de Castilla ligados directamente a los intereses mercantiles de Cádiz. Los empréstitos forzosos, las confiscaciones y el uso discrecional de las arcas públicas para sostener a las milicias fueron aislando cada vez más a Güemes y a sus partidarios del conjunto social. En pocas palabras, entre los miembros de la elite de Salta, que apoyaron a la revolución en sus primeros años, predominaba hacia 1820 un odio sincero por Güemes y una

66 AGN. Sala VII- Fondo Documental Sánchez de Bustamante. Documento 138. Año 1829. 
necesidad imperiosa de restituir el comercio con el Alto Perú, aunque esto significara abastecer al ejército realista a cambio de los apreciados y escasos pesos de plata. También percibían que el orden social estaba en peligro, que la insolencia de la "plebe" era intolerable y que la autoridad y respeto que merecían menguaba.

A pesar de conocer estos conflictos internos, en 1820, al restablecerse la Constitución en España, el Virrey de Perú solicitará al general realista Juan Ramírez que designe Comisionados para entablar negociaciones con los Jefes de las Provincias insurgentes, recomendándoles " [...] tratarán de ganar por todos los medios posibles al Gefe de la Provincia de Salta Don Martín Miguel de Güemes pues la incorporación de este en nuestro sistema acarrearía ventajas incalculables por su rango y por el gran influjo que ha adquirido sobre los pueblos de su mando". ${ }^{67}$

Estos comisionados nunca llegarán a entrevistarse con Güemes. A un intento frustado de la elite salteña por deponerlo a fines de mayo de 1821, le sucederá el ingreso de una partida realista una semana después que lo sorprenderá en circunstancias confusas, provocándole graves heridas y su posterior muerte. La firma de un armisticio entre el General conservador y absolutista de la Vanguardia del Ejército Real del Alto Perú, ${ }^{68}$ si bien no totalmente satisfactorio para Ramírez, generará en éste expectativas favorables para alcanzar la anhelada pacificación, al suponer que la muerte de Güemes y el armisticio constituían señales favorables. Los avatares políticos internos obligaron a la elite de Salta a designar a José Ignacio Gorriti a quien su proximidad con Güemes lo hizo viable para las milicias movilizadas y su acercamiento a ciertos sectores de la oposición garantizó su gestión, la única posible en ese momento de transición política, frente al levantamiento de las milicias rurales, ${ }^{69}$ las cuales, a pesar de la muerte de Güemes, habrán de continuar movilizadas durante largo tiempo.

67 Archivo General de Indias, Indiferente 1570. Los pueblos de su mando incluían además de Salta y Jujuy a los insurgentes altoperuanos.

68 Las negociaciones de Olañeta, resultantes de reuniones de carácter secreto entre la oposición a Güemes o autodenominada "Patria nueva" y el jefe realista, culminan con la firma de un armisticio en julio de 1821, mediante el cual se garantizaba el retiro de las tropas realistas más allá de la quebrada de Pumarmarca, se disponía la designación de un gobernador sin la presión de las tropas y se facilitaba la adquisición de vituallas y ganados a las fuerzas realistas, quienes debían pagar por ellas a comerciantes y propietarios que las facilitaran.

69 La designación del Gobernador fue negociada con el General realista quien deseaba imponer a un vecino de Salta que se había destacado por su fidelidad al Rey. En su lugar se nombró al más destacado de los opositores del fallecido Gobernador Güemes. Esta decisión no fue aceptada por las milicias leales a la facción de Güemes, quienes en septiembre invadieron la ciudad, la saquearon y lograron imponer como condición la renuncia del Gobernador. 
Ahora bien, ¿qué significación tuvo la firma del armisticio? No existía en ese momento un gobierno central y la provincia de Salta, acéfala, se constituyó en sujeto de soberanía que negoció el retiro de las tropas realistas y renunció también a continuar la guerra de independencia, con lo cual el proyecto de San Martín de reforzar con el ejército del Norte una avanzada hacia el Alto Perú se hizo trizas..$^{70}$ Se fracturó también la vinculación que en tiempos de Güemes existía entre las guerrillas altoperuanas y la provincia de Salta. El armisticio designó un territorio que ahora sí se diferenciaba políticamente con claridad del Alto peruano.

Los años de movilización de las milicias al enfrentar las reiteradas invasiones realistas produjeron un sentido de identidad política vinculado al propio espacio provincial. La elite de Salta mostró, en la crítica coyuntura de 1821, la existencia de diferentes proyectos políticos: algunos se mostraron favorables a reconocer la Constitución de España, mientras que otros conservaron la esperanza de conformar una comunidad política independiente de España. Prueba de ello es la respuesta que Gorriti dio a los Comisionados enviados por Ramírez para negociar el reconocimiento de la Provincia de Salta a la Corona española al exigirles para iniciar las conversaciones que previamente "[...] reconozcan la Independencia General que han jurado todas las provincias de América del Sud de la Metrópoli Española", ${ }^{71}$ clausurando así toda negociación.

\section{Reflexiones finales}

La experiencia política ensayada por el partido martiniano en Cuyo y del sistema Güemes en la provincia de Salta arrojan evidencias valiosas para restituir las formas en que la militarización, el peligro realista y los intereses locales precipitaron la cristalización de identidades provinciales y

70 En realidad San Martín en 1820 aspiraba a que el batallón de Cazadores acantonado en San Juan se uniera a las fuerzas de Güemes para ir hacia el Alto Perú, pero la rebelión auspiciada por el fenómeno Carrera hizo fracasar la empresa. Por otra parte, Güemes acosado por la oposición interna y con tropas indisciplinadas y poco propensas a dejar el territorio de su provincia tenía también pocas posibilidades de concretar esta aspiración sanmartiniana En 1824 la expedición hacia el Alto Perú partió bajo las órdenes de Juan Antonio Álvarez de Arenales, en ese momento gobernador de Salta, pero su llegada resultó tardía, ya que la victoria de Ayacucho y la muerte de Olañeta habían consagrado ya la independencia de América del Sur.

71 AGI, Indiferente 1570. 
nacionales de ninguna manera afines a las matrices románticas, sino coaguladas por el fervor patriótico, como resultado de la aceleración del proceso revolucionario y de las formaciones administrativas y territoriales previas a su emergencia. Desde la adhesión a la Junta provisional creada en Buenos Aires en reemplazo de la autoridad regia, y con la efímera excepción del experimento independiente de abril de 1815, que incidió en el declive de Alvear como Supremo Director de las Provincias Unidas, tanto Cuyo como Salta se mantuvieron fieles a los gobiernos surgidos de la Revolución. En ese resultado confluyen razones de índole variada entre ellas las de naturaleza estrictamente política que aparecen sintetizadas en los lazos políticos que reunían a los barones de un sector militar que la guerra puso en primer plano, que no sólo unían a profesionales sino que articulaban una densa trama de relaciones institucionales y políticas locales. Como se ha destacado, el caso de Cuyo revela que el poder sanmartiniano se sostuvo en un esquema de poder centralizado emblematizado, en el concepto de "gobierno de amigos sólidos" concurrieron los tenientes gobernadores de las ciudades subalternas de San Juan y San Luis, el arbitrio de la institución capitular de la capital de la Gobernación, el protagonismo de los comandantes de frontera y una compleja red de funcionarios menores distribuidos en ciudad y campaña. Esas lealtades políticas aunque estuvieran condicionadas, y sujetas a persistentes acechos, sin duda fueron más estables - aunque no menos violentas- que las exhibidas en el caso salteño en el cual las bases sociales del "sistema Güemes" y la permanencia de la guerra en Salta y área de influencia introducen aristas específicas ausentes en Cuyo al menos hasta $1820 .^{72}$

La existencia de diferentes escenarios así como la variada gama de actores que los dinamizaron no impide reconocer similares negociaciones con el gobierno central durante el crítico año 1815, negociaciones que dependían de equilibrios políticos inestables pero que colaboraron en la estabilidad del gobierno revolucionario como barrera contra la denunciada "anarquía" hasta su fractura definitiva en 1820. Si el fin de la preeminencia del partido martiniano en Cuyo fue simultánea a ella, revelando entre otras cosas las fatigas de la guerra, la agonía del sistema güemesiano, se explica en la insuficiencia de recursos para sostener una guerra prolongada

72 Bragoni, Beatriz: "Fragmentos de poder. Política, rebelión y fragmentación territorial en Cuyo, 1820”, Boletín del Instituto de Historia Americana y Argentina, Dr. Emilio Ravignani, n. ${ }^{\circ} 28,3{ }^{a}$ Serie, 2. ${ }^{\circ}$ semestre de 2005, págs. 39-59. 
que socavaba las bases de construcción política abriendo el camino a una oposición proclive a la integración política con las provincias altoperuanas que, sin embargo, no tuvo garantías de prosperar. Ninguna sincronía puede hallarse en las oposiciones visualizadas para el caso cuyano; a pesar de San Martín, las acciones de los sanmartinianos parecen haber fortalecido las identidades políticas nacidas a partir de 1810 sea en clave rioplatense en oposición al experimento político chileno, sea en clave centralista opuesta a formatos federativos.

Semejantes contrapuntos no inhiben reconocer un núcleo de coincidencias en torno a las identidades políticas que la militarización y la guerra habían creado a lo largo de la experiencia guerrera dirigida, con cooperación o no, desde la sede del gobierno revolucionario. No en vano en 1825 Sucre podía confesarle a Bolívar la centralidad de estos espacios locales en la permanencia del gobierno de Buenos Aires:

\begin{abstract}
"Haré a U.una confesión, sólo para U.; si sus cartas no me hubieran azorado tanto sobre estos negocios del Río de la Plata, les hubiéramos hecho una burla graciosa a esos escritores insolentes y partidarios groseros del Gobierno de Buenos Aires; esta burla era no más que hacerles separar las provincias y unirlas a estas, dejando aislado al tal Buenos Aires, sin comprometernos nosotros en nada. Salta y Tucumán están bien dispuestos por que sus disgustos no se concilian con la capital; Córdova con una palabra ardía, pues existen resentimientos; de Mendoza no se cómo está; las demás provincias no valen la pena". ${ }^{73}$
\end{abstract}

Si el caso salteño permite apreciar la manera en que ese espacio corroído por la guerra de recursos y disputas facciosas clausuró la posibilidad de sumar su adhesión a la naciente república boliviana, la emergencia de las tres provincias cuyanas revelan un proceso de fragmentación que está lejos de representar un ejercicio prolongado de "soberanías independientes" en la medida que las nociones que la sostienen suponen el restablecimiento de vínculos políticos entre las provincias de la antigua unión. De que esa experiencia más allá de su fracaso había servido para crear lazos políticos e identitarios comunes dio cuenta la experiencia peregrina y guerrera del teniente coronel José María Aguirre que de ningún modo había impedido, sino que había forjado la formación de identidades políticas "nacionales". En 1825 al evocar la campaña de la sierra, y a diferencia de Sucre, Aguirre no dudaba en expresar: "El regimiento más fuerte y más

73 Carta fechada en Cochabamba el 11 de junio de 1825 (O’Leary, 1981, tomo 1, pág. 278). 
acreditado que tenía el ejército del Rey era el de Numancia. Éste se pasó a las banderas de la patria, porque todos eran colombianos [...] Entonces arrojó la cucarda española, y substituyó en su lugar la escarapela colombiana, a que por origen pertenecía. Desde entonces ya el ejército se compuso de tres escarapelas americanas unidas" ${ }^{74}$ Es decir, la colombiana, la chilena y la argentina.

Recibido el 10 de octubre de 2005 Aceptado el 5 de marzo 2006

74 Compendio de las campañas del ejército de los Andes publicado por un jefe amante de las glorias de la patria, Buenos Aires, Impreso de la Imprenta del Estado, 1825. 